\title{
Evaluation of five commercial assays for screening antenatal sera for antibodies to Toxoplasma gondii
}

\author{
W D Cubitt, A E Ades, C S Peckham
}

\begin{abstract}
Aims: To evaluate the suitability of five commercial assays (Toxoreagent, DA, Captia Toxo IgG, Toxenz-G, Toxonostika-G) for screening large numbers of sera for antibodies to Toxoplasma gondii.
\end{abstract}

Methods: Sera from 1000 pregnant women booking for antenatal care at a London hospital were screened in parallel by each test. Sera giving discordant results were retested.

Results: The Captia Toxo IgG enzyme immune assay gave the best specificity on initial screening, with $0 / 773$ false positives and only 2/218 false negatives. The Toxoreagent latex agglutination test performed well provided sera were tested at several dilutions to prevent prozone effects; $0 / 218$ false negatives ( $>12 \mathrm{IU} / \mathrm{ml}$ ). Only one evidently false positive result was seen in the 1000 samples tested. The DA test gave no false negative results but produced 23/773 false positives.

After repeat testing there were $9 / 1000$ sera which gave equivocal results which were negative by the Captia Toxo IgG test $(<12 \mathrm{IU} / \mathrm{ml})$ but with low titres of 16 in the Toxoreagent test or $4 \mathrm{IU} / \mathrm{ml}$ in the $D A$ test. In this situation women would have been asked for a follow up sample for repeat testing.

Only 300 sera were tested by Toxenz-G; initial screening produced 4/58 false negative results and 4/242 false positives. Conclusions: The Captia Toxo IgG test gave the fewest discordant results on initial screening. Results could be readily expressed in international units using a programmable plate reader, and this may be useful for epidemiological studies. The Toxoreagent test is considerably cheaper, and is a simple and reliable method for screening provided that at least two dilutions are used.

Department of

Hospitals for Sick

Children, and the

Epidemiology and Biostatistics Unit, Institute of Child

Health, London

W D Cubitt

A E Ades

C S Peckham

Correspondence to

Dr W D Cubitt, Department of Virology, Institute of Child Health, 30 Guilford

Street, London WCIN 1EH

Accepted for publication 30 October 1991

Recently there has been considerable controversy over whether or not to screen pregnant women for antibodies to Toxoplasma gondii as a means of trying to reduce the number of congenitally damaged babies in the UK. ${ }^{1-5}$ In response to questions arising from this debate we set up a study to screen sera obtained from 8000 pregnant women attending antenatal clinics at two London hospitals. The pilot study presented here was set up to evaluate commercially available assays to determine which was the most suitable for screening large numbers of patients for evidence of past infection.

\section{Materials}

Sera obtained from 1000 pregnant women booking consecutively for antenatal care at a London hospital were availale for testing. These had been collected and stored for 10 years at $-20^{\circ} \mathrm{C}$. During this time they were thawed and frozen for use in other seroepidemiological surveys ${ }^{67}$ on several occasions but not heat inactivated.

\section{Methods}

The presentation and cost of each assay are shown in table 1 . All tests were performed according to the manufacturer's instructions (see table 2). A programmable plate washer (Denley Instruments Ltd, Billingshurst, UK) was used for all enzyme immunoassays (EIAs). Any samples which gave discordant results when compared with the other tests were retested. In order to make an assessment of sensitivity and specificity of each test on the initial screen, in the case of initially discordant results the true serodiagnosis was based on the results of repeat tests.

DIRECT AGGLUTINATION TEST (DA)

The Biomerieux DA test (API-Biomerieux, Basingstoke, Hants, UK) relies on formalin treated Toxoplasma agglutinating in the presence of diluted serum containing specific IgG. IgM is removed by treatment with 2mercaptoethanol incorporated in the dilution buffer. Sera were tested at dilutions of 1:40 and 1:4000.

The positive control included in the kit was run on every plate. Sera with titres of IgG $\geqslant 40$ (equivalent to $4 \mathrm{IU} / \mathrm{ml}$ ) were regarded as positive.

\section{LATEX AGGLUTINATION TEST}

The Toxoreagent (Eiken) test depends on latex particles coated with inactivated Toxoplasma antigen forming agglutination patterns in the presence of specific IgM or IgG antibodies. were screened at a dilution of $1: 16$. Sera which gave positive reactions or results discordant with results obtained in other assays, were retested at a series of doubling dilutions ( $1: 16$ to $1: 2048$ ). The positive control provided in the kit was included on each plate.

The endpoint was taken as the highest dilution displaying a definite agglutination pattern. 
Table 1 Constituents of five commercial assays for detection of antibodies to Toxoplasma gondii

\begin{tabular}{|c|c|c|c|c|c|}
\hline Assay & $\begin{array}{l}\text { DA } \\
\text { (Biomerieux) }\end{array}$ & $\begin{array}{l}\text { Toxoreagent } \\
\text { (Eiken) }\end{array}$ & $\begin{array}{l}\text { Captia Toxo IgG } \\
\text { (Mercia) }\end{array}$ & $\begin{array}{l}\text { Toxenz-G } \\
(N B L)\end{array}$ & $\begin{array}{l}\text { Toxonostika- } G \\
\text { (Organon) }\end{array}$ \\
\hline $\begin{array}{l}\text { Type of assay } \\
\text { Solid phase } \\
\text { Antigen } \\
\text { Conjugate }\end{array}$ & $\begin{array}{l}\text { Agglutination } \\
\text { NA } \\
\text { Formalinised } \\
\text { Toxoplasma } \\
\text { NA }\end{array}$ & $\begin{array}{l}\text { Agglutination } \\
\text { Polystyrene latex } \\
\text { Inactivated } \\
\text { Toxoplasma } \\
\text { NA }\end{array}$ & \multirow{3}{*}{$\begin{array}{l}\text { ELISA } \\
\text { Microplate } \\
\text { Inactivated } \\
\text { Toxoplasma } \\
\text { HRP anti-human } \\
\text { IgG, (rabbit) } \\
\text { TMB } \\
2 \mathrm{M} \mathrm{H}_{2} \mathrm{SO}_{4}{ }^{\star} \\
450 \mathrm{~nm} \\
\mathrm{PBS}, 0 \cdot 05 \% \text { tween, } \\
20 \times \text { concentrate } \\
2-8^{\circ} \mathrm{C}\end{array}$} & \multirow{3}{*}{$\begin{array}{l}\text { ELISA } \\
\text { Microplate } \\
\text { Inactivated } \\
\text { Toxoplasma } \\
\text { HRP anti-human } \\
\text { IgG, (swine) } \\
\text { TMB } \\
5 \mathrm{~N} \mathrm{H}_{2} \mathrm{SO}_{4} \\
450 \mathrm{~nm} \\
\mathrm{Saline} / \text { tween } 20 \text {, } \\
30 \times \text { concentrate } \\
2-8^{\circ} \mathrm{C}\end{array}$} & \multirow{3}{*}{$\begin{array}{l}\text { ELISA } \\
\text { Microplate } \\
\text { Inactivated } \\
\text { Toxoplasma } \\
\text { HRP anti-human } \\
\text { IgG, (sheep) } \\
\mathrm{TMB} \\
2 \mathrm{M} \mathrm{H}_{2} \mathrm{SO}_{4}{ }^{\star} \\
450 \mathrm{~nm}^{-} \\
\mathrm{PBS}, 25 \times \\
\text { concentrate } \\
2-8^{\circ} \mathrm{C}\end{array}$} \\
\hline $\begin{array}{l}\text { Substrate } \\
\text { Stop solution } \\
\text { Reading } \\
\text { Wash fluid }\end{array}$ & $\begin{array}{l}\text { NA } \\
\text { NA } \\
\text { Visual } \\
\text { NA }\end{array}$ & $\begin{array}{l}\text { NA } \\
\text { NA } \\
\text { Visual } \\
\text { NA }\end{array}$ & & & \\
\hline $\begin{array}{l}\text { Storage temp: } \\
\text { Control (wells/run) }\end{array}$ & $2-8^{\circ} \mathrm{C}$ & $2-10^{\circ} \mathrm{C}$ & & & \\
\hline $\begin{array}{l}\text { High } \\
\text { Low } \\
\text { Neg } \\
\text { Blank }\end{array}$ & $\frac{2}{2}$ & $\frac{8}{-}$ & $\begin{array}{l}2 \\
2 \\
2 \\
-\end{array}$ & $\begin{array}{l}1 \text { or } 2 \\
1 \text { or } 2 \\
1 \text { or } 2 \\
1 \text { or } 2\end{array}$ & $\begin{array}{l}2 \\
2 \\
2 \\
-\end{array}$ \\
\hline $\begin{array}{l}\text { Wells/test } \\
\text { Cost/kit } \\
\text { Cost/well }\end{array}$ & $\begin{array}{l}2 \\
f_{55 \mathrm{p}} 105.6 \\
\end{array}$ & $\begin{array}{l}1 \text { or } 2 \text { screening } \\
f_{43} .95 \\
9 \mathrm{p}\end{array}$ & $\begin{array}{l}1 \\
f_{1110} \\
114 \mathrm{p}\end{array}$ & $\begin{array}{l}1 \\
f 58 \cdot 00 \\
120 \mathrm{p}\end{array}$ & $\begin{array}{l}1 \\
f 202 \\
105 p\end{array}$ \\
\hline
\end{tabular}

$\star$ Not provided in kit.

Table 2 Stages and approximate times to run a 96 well plate

\begin{tabular}{|c|c|c|c|c|c|}
\hline & $\begin{array}{l}\text { DA } \\
\text { (Biomerieux) }\end{array}$ & $\begin{array}{l}\text { Toxoreagent } \\
\text { (Eiken) }\end{array}$ & $\begin{array}{l}\text { Captia Toxo IgG } \\
\text { (Mercia) }\end{array}$ & $\begin{array}{l}\text { Toxenz-G } \\
(N B L)\end{array}$ & $\begin{array}{l}\text { Toxonostika-G } \\
\text { (Organon) }\end{array}$ \\
\hline $\begin{array}{l}\text { Specimen volume } \\
\text { Dilution } \\
\text { Time } \\
\text { Loading plate } \\
\text { 1st incubation } \\
\text { No of washes/time } \\
\text { Conjugate time } \\
\text { No of washes/time } \\
\text { Substrate time } \\
\text { Stop and reading } \\
\text { No of steps } \\
\text { Approx time }\end{array}$ & $\begin{array}{l}100 \mu \mathrm{l} \\
1: 20 \text { and } 1: 2000 \\
1 \mathrm{~h} \\
10^{\prime} \\
5 \mathrm{~h} \text { at } 18-25^{\circ} \mathrm{C} \\
- \\
- \\
- \\
\overline{5^{\prime}} \\
4 \\
6 \mathrm{~h}\end{array}$ & $\begin{array}{l}50 \mu \mathrm{l} \\
1: 8 \\
1 \mathrm{~h} \\
10^{\prime} \\
12 \mathrm{~h} \text { at RT } \\
- \\
= \\
- \\
\overline{5^{\prime}} \\
4 \\
13 \mathrm{~h}\end{array}$ & $\begin{array}{l}10 \mu \mathrm{l} \\
1: 101 \\
1 \mathrm{~h} \\
10^{\prime} \\
1 \mathrm{~h} \text { at } 37^{\circ} \mathrm{C} \\
3 \times / 3^{\prime} \\
1 \mathrm{~h} \text { at } 37^{\circ} \mathrm{C} \\
3 \times / 3^{\prime} \\
30^{\prime} \\
2^{\prime} \\
8 \\
4 \mathrm{~h}\end{array}$ & $\begin{array}{l}10 \mu \mathrm{l} \\
1: 50 \\
1 \mathrm{~h} \\
10^{\prime} \\
30^{\prime} \text { at } 15-20^{\circ} \mathrm{C} \\
3 \times / 3^{\prime} \\
1 \mathrm{~h} \text { at } 15-20^{\circ} \mathrm{C} \\
3 \times / 3^{\prime} \\
30^{\prime} \\
2^{\prime} \\
8 \\
3.5 \mathrm{~h}\end{array}$ & $\begin{array}{l}10 \mu \mathrm{l} \\
1: 101 \\
1 \mathrm{~h} \\
10^{\prime} \\
1 \mathrm{~h} \text { at } 37^{\circ} \mathrm{C} \\
3 \times / 3^{\prime} \\
1 \mathrm{~h} \text { at } 37^{\circ} \mathrm{C} \\
3 \times / 3^{\prime} \\
30^{\prime} \\
2^{\prime} \\
8 \\
4 \mathrm{~h}\end{array}$ \\
\hline
\end{tabular}

Sera with titres of $\geqslant 16$ were regarded as positive.

\section{ENZYME IMMUNOASSAYS (EIA)}

EIAs specific for Toxoplasma IgG were obtained from three commercial suppliers; Captia Toxo IgG (Mercia Diagnostics, Guildford, Surrey, UK); Toxenz-G (Northumbria Biologicals, Cramlington, Northumberland, UK); and Toxonostika-G (Organon Teknika, Cambridge, UK).

All tests are indirect EIAs; plastic microtitre plates are coated with Toxoplasma antigen which complexes with specific antibodies in diluted sera. Unbound antibodies are washed away and an anti-human IgG-horseradish peroxidase conjugate added.

Following a second series of washes bound complexed enzyme is detected by reaction with $3,3^{\prime}, 5,5^{\prime}$-tetramethylbenzidine. The reaction is stopped with sulphuric acid and the optical density read at a wavelength of $450 \mathrm{~nm}$ in a spectrophotometer.

\section{Captia toxo $\operatorname{IgG}$}

Tests were carried out in eight well strips. A standard curve was obtained by running the high positive control, $400 \mathrm{IU} / \mathrm{ml}$ neat and as a series of doubling dilutions, $200 \mathrm{IU} / \mathrm{ml}$ to 50 $\mathrm{IU} / \mathrm{ml}$ and the low positive control, $12 \mathrm{IU} / \mathrm{ml}$ on each plate. The optical densities (OD) were read in an SLT EIA reader (Mercia Diagnostics, Guildford, Surrey, UK) programmed to calculate a standard curve. Results expressed in $\mathrm{IU} / \mathrm{ml}$ were automatically derived from the standard curve and sera with titres of IgG $\geqslant 12$ $\mathrm{IU} / \mathrm{ml}$ regarded as positive.

\section{Toxenz-G}

Tests were performed in 12 well strips and 1:50 dilutions of sera were added to antigen coated and uncoated (control) wells.

The high, low, and negative controls were included on every plate. Specimens giving corrected ODs (absorbance of antigen coated well - absorbance of uncoated well) which were greater than the value for the low positive control $(20 \mathrm{IU} / \mathrm{ml})$, were recorded as positive. Samples giving ODs between $90 \%$ and $99 \%$ of the low positive were considered to be equivocal and those that were less than $90 \%$ were regarded as negative.

\section{Toxonostika-G}

Sera were tested at a dilution of 1:101. The calibrator, $320 \mathrm{IU} / \mathrm{ml}$, and a positive control (P), $20 \mathrm{IU} / \mathrm{ml}$ in the kit, were run on each plate in order to obtain a standard curve. Results could then be expressed in $\mathrm{IU} / \mathrm{ml}$ with samples giving titres of $\geqslant 10 \mathrm{IU} / \mathrm{ml}$ recorded as positive.

\section{Results}

Initial screening produced 951 concordant results, 205 which were positive in three assays (DA, Toxoreagent, Captia Toxo IgG) and 746 which were negative, $<12 \mathrm{IU} / \mathrm{ml}$. There were 49 discordant results, classed on the screening pattern in table 3a-d. After repeat testing concordant results in the DA, Toxoreagent, 
Table 3 Results of repeat testing of 49 samples with discordant results on initial screening

\begin{tabular}{|c|c|c|c|c|c|}
\hline & Toxoreagent & $D A$ test & $\begin{array}{l}\text { Captia } \\
\text { Toxo IgG }\end{array}$ & Total & Interpretation \\
\hline $\begin{array}{l}\text { a } \\
\text { Primary screen } \\
\text { Repeat test }\end{array}$ & $\begin{array}{l}+ \\
1: 16 \\
1: 16 \\
1: 16\end{array}$ & $\begin{array}{rl}+ & \\
>400 & \mathrm{IU} / \mathrm{ml} \\
4 \mathrm{IU} / \mathrm{ml} & \\
4 \mathrm{IU} / \mathrm{ml}\end{array}$ & $\begin{array}{l}\overline{+} \\
+ \\
+1-\end{array}$ & $\begin{array}{l}3 \\
1 \\
1 \\
1\end{array}$ & $\begin{array}{l}+ \\
+ \\
\text { Equivocal }\end{array}$ \\
\hline $\begin{array}{l}\text { Primary screen } \\
\text { Repeat test }\end{array}$ & $\overline{+}$ & $\begin{array}{l}+ \\
+\end{array}$ & $\begin{array}{l}+ \\
+\end{array}$ & $\begin{array}{l}11 \\
11\end{array}$ & + \\
\hline $\begin{array}{l}\text { c } \\
\text { Primary screen } \\
\text { Repeat test }\end{array}$ & $\begin{array}{l}+ \\
1: 16 \\
1: 128\end{array}$ & $\bar{z}$ & $\begin{array}{l}- \\
- \\
-\end{array}$ & $\begin{array}{l}5 \\
4 \\
1\end{array}$ & $\begin{array}{l}\text { Equivocal } \\
\text { False positive }\end{array}$ \\
\hline $\begin{array}{l}\text { a } \\
\text { Primary screen } \\
\text { Repeat test }\end{array}$ & $\begin{array}{l}- \\
- \\
-\end{array}$ & $\begin{array}{l}+ \\
- \\
\geq 400 \mathrm{IU} / \mathrm{IU} / \mathrm{ml}\end{array}$ & $\begin{array}{l}- \\
- \\
-\end{array}$ & $\begin{array}{r}30 \\
23 \\
4 \\
3\end{array}$ & $\begin{array}{l}\text { Equivocal } \\
\text { False positive }\end{array}$ \\
\hline
\end{tabular}

and Captia IgG tests showed that sera from $218 / 1000$ pregnant women contained concentrations of Toxoplasma IgG of $\geqslant 12 \mathrm{IU} / \mathrm{ml}$. A further five samples gave an equivocal pattern but were positive in the DA test at a titre of 40 (4 IU $/ \mathrm{ml})$; one of these gave a low positive titre of 16 in the Toxoreagent assay.

Four samples gave low positive titres of 16 in the Toxoreagent assay, but were negative in the other assays; 773 sera were considered to be negative.

\section{DA TEST (BIOMERIEUX)}

The DA test was found to be extremely sensitive with no false negative results. However, there were 23 false positives out of the 773 presumed negative sera (specificity $=97 \%$ ) on initial screening which were negative in all three assays when retested (table $3 \mathrm{~d}$ ). Three samples repeatedly gave high titres $>400 \mathrm{IU} /$ $\mathrm{ml}$ but were negative by the Toxoreagent and Captia IgG assays (table 3d).

\section{TOXOREAGENT (EIKEN)}

Initial screening of the sera at a single dilution (1:16) for the presence of antibodies to Toxoplasma produced many discordant results (table 3a-d). After retesting these sera at a series of doubling dilutions, 11 were found to have high titres (table $3 b$ ); prozoning accounted for a lack of agglutination at a dilution of $1: 16$. One sample repeatedly gave a positive result at $1: 128$ but was negative in the other assays (table 3c). Another seven samples repeatedly gave weak positive results (titre $=16$ ) (table $3 a, c)$. Three of these samples were positive in the DA tests, two had titres of $4 \mathrm{IU} / \mathrm{ml}$, and the other $400 \mathrm{IU} / \mathrm{ml}$.

TOXO CAPTIA IGG (MERCIA)

The sensitivity of the test on initial screening was $99 \cdot 1 \%$ with $216 / 218$ positive. Three samples gave discordant results, (table 3a); two were recorded as negative, $<12 \mathrm{IU} / \mathrm{ml}$ but were positive in other assays; one sample repeatedly gave an equivocal result and was positive at a dilution of $1: 40(4 \mathrm{IU} / \mathrm{ml})$ in the DA test, and 1:16 by Toxoreagent. Two of the three initially discordant results were found to be false negatives. There were no false positives.
TOXENZ-G (NORTHUMBRIA BIOLOGICALS)

Due to the unavailability of kits only 300 sera were tested. The sensitivity of the assay on the initial screen was $93 \cdot 1 \%$, $(54 / 58)$ positives. There were four positive and four negative results which differed from those in all the other assays. Repeat testing produced only two discordant results; these were positive in the NBL EIA but negative in all the other assays.

TOXONOSTICA-G (ORGANON)

Sufficient kits were available to test 700 sera in parallel with the other assays. The sensitivity was good, $99.3 \%$ of positive samples were detected in the initial screen with only one false negative result but the specificity was poor with 17 false positives. However, 16/18 discrepant results were associated with one batch of tests in which the cut-off threshold appeared to be too low, resulting in a series of weak positives in the range of $10-20 \mathrm{IU} / \mathrm{ml}$.

\section{Discussion}

The Biomerieux DA test, which has been widely used in France for many years for screening women during pregnancy, ${ }^{8}$ gave the most discordant results, probably because the cut-off is considerably lower, $4 \mathrm{IU} / \mathrm{ml}$, than for the EIAs, 10-20 IU/ml. However, 23/30 sera which gave discordant positive results on initial screening became negative when tested using a different batch of antigen, suggesting that all low level positive results should be repeated and interpreted with caution. The age of the sera and repeated freezing and thawing may have contributed to some of these discrepancies.

The test is easy to perform but preparation of several dilutions is cumbersome when screening large numbers of sera. Interpretation of results is visual and dependent on the observer, whereas results from EIA tests can be read using a spectrophotometer which automatically determines the concentration of antibody present. The cost per test is similar to that of the Captia Toxo IgG and Toxonostika-G EIAs.

The Toxoreagent test is easy to perform and considerably cheaper than any of the other assays. Disadvantages are that titrations have to be performed to obtain quantitative results. Often at least two serum dilutions are required to prevent false negative results due to prozoning and reading of the plates cannot readily be automated. One possible advantage of the Toxoreagent test in the antenatal context is that it detects total antibody whereas the other assays are specific for $\mathrm{IgG}$.

In the present study we found only one definite false positive result at a dilution of 1:128 among the 1000 sera tested. This is in contrast to the results obtained in some previous evaluations. ${ }^{910}$ Holliman et al ${ }^{11}$ found that $59 / 4450(1.3 \%)$ latex agglutination reactions were not confirmed in the dye test; the majority of patients giving false reactions had malignancies, HIV or were transplant recipients, which are groups of patients which may have been absent in the population we screened. 
The EIA tests were all easy to perform and results could be obtained the same day. An advantage of the Captia IgG test was that results were easily expressed in international units by including a set of standards in each assay. Only 300 samples were tested in the Toxenz-G assay due to failure of a batch to pass through the manufacturer's internal quality control. This feature is unfortunately a quite common occurrence with commercially available EIA kits and can cause considerable disruption when a laboratory is committed to large scale screening programmes.

The Toxoreagent and Captia ToxoIgG tests gave the least number of discordant results and were therefore considered as the methods of choice for screening further sera. Although it was considerably more expensive, the Captia ToxoIgG test has the advantage of giving quantitative results which may provide useful epidemiological information.

This project was supported by a grant from The Child Health Research Appeal Trust.

We would like to thank API-Biomerieux, Mercia Diagnostics,
Northumbria Biologicals, Organon Teknika, and Mast Diagnostics for supplying kits at a considerable discount, and Mary Araboga for technical support.

1 Joynson DHM, Payne R. Screening for Toxoplasma in pregnancy. Lancet 1988;ii:795-6.

2 Siragusa JJ, McDermott WM, Amorosino CS. Toxo plasmosis. The time has come. $N$ Engl J Med 1988;318: $1135-9$.

3 Antenatal screening for toxoplasmosis in the UK. Lancet 1990;ii:346-8.

4 Ho Yen DO, Chatterton JMW. Congenital toxoplasmosiswhy and how to screen. Rev Med Microbiol 1990;1:229-35.

5 Joss AWL, Chatterton JMW, Ho Yen DO. Congenital toxoplasmosis: to screen or not to screen? Public Health toxoplasmosis:

6 Peckham CS, Chin KS, Coleman JC, et al. Cytomegalovirus in pregnancy. Preliminary findings from a prospective study. Lancet 1983;ii:1352-5.

7 Ades AE, Peckham CS, Dale GE, et al. Prevalence of antibodies to herpes simplex virus types 1 and 2 in pregnant women, and estimated rates of infection. $J$ Epidemiol Community Health 1989;43:53-60

8 Desmonts G, Remington JS. Direct agglutination test for diagnosis of Toxoplasma infection. Method for increasin specificity and sensitivity. J Clin Microbiol 1980,11:562-8.

9 Ise Y, Iida in the Toxoplasma latex agglutination test. Jpn J Parasitol 1981;30:579-85.

10 Wreghitt JG, Gray JJ, Balfour AH. Problems with the serological diagnosis of Toxoplasma gondii infections in heart transplant recipients. J Clin Pathol 1986;39:1135-9.

heart transplant recipients. J Clin Pathol 1986;39:1135-9.
11 Holliman RF, Johnson J, Duffy K, New L. Discrepan Toxoplasma latex agglutination test results. J Clin Patho 1989;42:200-3. 